\title{
PENINGKATAN DAYA SAING UKM ROTAN INDAH JEPARA MENUJU PASAR SASARAN EKSPOR
}

\author{
A. Khoirul Anam ${ }^{1}$, Miftah Arifin ${ }^{2}$, Anna Widiastuti $^{3}$, Zainul Arifin ${ }^{4}$ \\ Universitas Islam Nahdlatul Ulama Jepara \\ email: anam@unisnu.ac.id \\ Universitas Islam Nahdlatul Ulama Jepara \\ email:miftah@unisnu.ac.id \\ Universitas Islam Nahdlatul Ulama Jepara \\ email: annafeb2013@gmail.com \\ Universitas Islam Nahdlatul Ulama Jepara \\ email: zainularifin@unisnu.ac.id
}

\begin{abstract}
Rattan craft is one of the regional superior products in Jepara. Because the products have high quality, they are able to compete in the international market. However, the presence of rattan handicrafts also experienced ups and downs, both at local, national and international trade. Therefore, it is necessary to increase the competitiveness of rattan craftsmen through a mentoring program from the service program at SME of Rotan Indah Jepara. The strategic value of the assisted partner is increasing competitiveness towards the export market through approaches to the application of appropriate science and technology, enhancing the quality and quantity of production, and strengthening institutional capacity. The achievement of the target shows the accuracy of the assistance method used. Several programs have been carried out, including strengthening production equipment and implementing appropriate technology, strengthening product capacity and quality, strengthening marketing capacity, and strengthening corporate governance, compiling accounting systems and computerized financial reporting. The results of this program show that all the targets can be realized. The impact and benefits of this service program are social changes, effectiveness and increased productivity, in the form of increased sales turnover, changes in better work patterns, increased production capacity due to changes in work patterns, systems and technology used. Another added value is shown to be significant savings from good management patterns and more efficient production processes.
\end{abstract}

Keywords: competitiveness; rattan crafts; export potential

\section{ABSTRAK}

Kerajinan rotan merupakan salah satu produk unggulan daerah di Jepara. Karena Produk ini memiliki kualitas yang tinggi, produk ini mampu bersaing di pasar internasional. Namun, keberadaan kerajinan rotan juga mengalami pasang surut, baik pada perdagangan skala lokal, nasional maupun internasional. Oleh karena itu, perlu peningkatan daya saing pengrajin rotan melalui program pendampingan dari program pengabdian pada UKM Rotan Indah Jepara. Nilai strategis UKM mitra binaan adalah peningkatan daya saing menuju pasar ekspor melalui pendekatan penerapan sains dan teknologi tepat guna, peningkatan kualitas dan kuantitas produksi, serta penguatan 
kapasitas kelembagaan. Ketercapaian target menunjukkan ketepatan metode pendampingan yang digunakan. Beberapa program yang dijalankan, yaitu penguatan peralatan produksi dan implementasi teknologi tepat guna, penguatan kapasitas dan kualitas produk, penguatan kapasitas pemasaran, dan penguatan tata kelola perusahaan, penyusunan sistem akuntansi dan pelaporan keuangan terkomputerisasi. Hasil dari program ini menunjukkan bahwa semua target yang ditetapkan dapat direalisasikan. Dampak dan manfaat dari program pengabdian ini adalah adanya perubahan sosial, efektivitas dan peningkatan produktivitas, berupa peningkatan omset penjualan, perubahan pola kerja yang lebih baik, peningkatan kapasitas produksi karena adanya perubahan pola kerja, sistem dan teknologi yang digunakan. Value added yang lain ditunjukkan adanya penghematan yang cukup signifikan dari pola manajemen yang baik dan proses produksi yang lebih efisien.

Kata Kunci: daya saing; kerajinan rotan; potensi ekspor

\section{PENDAHULUAN}

Kerajinan rotan di Jepara merupakan salah satu bentuk kreativitas masyarakat yang berkontribusi dalam penyediaan lapangan kerja bagi masyarakat setempat. Kerajinan ini sudah ada sejak tahun 1972 dan berkembang hingga saat ini, menjadi salah satu produk unggulan daerah. Namun demikian, keberadaan kerajinan rotan juga mengalami pasang surut, baik pada perdagangan skala lokal, nasional maupun internasional. Sehingga perlunya peningkatan daya saing pengrajin rotan dan perluasan pasar ekspor bagi produk kerajinan rotan di Jepara, serta penguatan kerajinan anyaman rotan sebagai industri kreatif dengan ciri khas daerah.

Beberapa faktor yang mempengaruhi perkembangan industri rotan ini diantaranya dilihat dari strategi dan inovasi. Dari segi strategi, keberadaan dari paguyuban sentra industri dan model pengembangan klaster mendorong diseminasi dan menciptakan inovasi produk-produk baru, kualitas dan harga produk yang kompetitif, serta dukungan pemasaran online (Anam \& Setyawan, 2019). Sedangkan dari segi inovasi, selain penggunaan bahan baku utama berupa rotan alam juga menggunakan bahan rotan sintetis, eceng gondok, debog, alumunium dan besi. Dari perpaduan bahan baku tersebut menghasilkan berbagai produk kerajinan souvenir dan furniture yang bernilai tinggi, sehingga mampu bersaing di pasar internasional. (Bigliardi, Colacino, \& Dormio, 2011) menyatakan bahwa jenis inovasi yang banyak berlaku di UKM adalah inovasi produk, proses dan pemsaran. Inovasi juga didukung implementasi teknologi tepat guna (TTG) bagi UKM, sehingga dihasilkan produk dengan kualitas baik, lebih presisi dan proses pengerjaan lebih cepat (Anam \& Susilo, 2018)

Eksistensi dan perkembangan kerajinan rotan di Jepara juga dipengaruhi oleh beberapa faktor, diantaranya faktor keluarga karena pengusaha jenis ini biasanya meneruskan usaha keluarga, faktor lingkungan tempat tinggal yang merupakan sentra industri kerajinan, sehingga terdorong untuk mendirikan usaha kerajinan rotan serta faktor memenuhi kebutuhan ekonomi (Alamsyah, 2019). Dalam menghadapi persaingan bisnis dan lingkungan usaha yang semakin kompetitif, industri kerajinan rotan harus 
memiliki daya saing yang tinggi, diantaranya diperlukan pengelolaan mata rantai produksi yang efektif. Peningkatan daya saing suatu bisnis akan meningkatkan ketahanan sebuah industri kerajinan (Kurniaty, Fauzi, \& Chozin, 2012).

Sebagai upaya peningkatan daya saing bagi pengrajin rotan, dilaksanakan program pengabdian pada UKM Rotan Indah Jepara. Rotan Indah Jepara merupakan salah satu UKM kerajinan rotan yang berada di kawasan sentra kerajinan anyaman rotan dan bambu, yang berpusat di Kecamatan Welahan Kabupaten Jepara. Produk yang dihasilkan antara lain kursi makan, kursi teras, sofa, daybed, ayunan, handicraft, lampu hias, gazebo serta berbagai asesoris kerajinan lainnya. Produk yang dihasilkan bernilai tinggi sehingga sehingga tidak hanya diminati oleh pasar lokal maupun nasional namun juga pasar internasional. Produk sasaran pasar internasional yang diproduksi oleh Rotan Indah Jepara diantaranya kursi, keranjang dan berbagai asesoris berbahan rotan. Potensi yang dimiliki oleh UKM mitra program tersebut belum dapat dioptimalkan dikarenakan adanya berbagai keterbatasan baik yang ada pada bidang produksi, manajemen, pemasaran dan bidang SDM. Pada bidang produksi meskipun mampu menghasilkan produk dengan kualitas tinggi namun tidak dimbangi dengan kuantitas yang mampu dihasilkan, peralatan produksi masih sederhana dan belum memadai, tempat produksi yang belum memadai serta ketergantungan pada cuaca maupun suplai listrik berkaitan dengan produksi dan proses finising. Pada bidang manajemen, persoalan yang dihadapi belum memiliki perijinan/legalitas usaha, kemampuan manajerial yang lemah dan manajemen usaha masih tradisional serta pengelolaan keuangan belum dilakukan dengan baik. Pada bidang pemasaran, saat ini pemasaran yang dilakukan masih tradisional, lebih banyak menunggu, mengandalkan pesanan dan ketergantungan penjualan pada perusahaan besar serta belum ada upaya promosi yang memadai. Meskipun mampu menghasilkan produk dengan kualitas ekspor namun masih bersifat dijual pada perusahaan besar untuk kemudian diekspor. Sedangkan pada bidang SDM, jumlah tenaga kerja yang terbatas, serta pengelolaan dan pengembangan SDM belum dilakukan.

Nilai strategis UKM mitra binaan adalah peningkatan daya saing menuju pasar sasaran ekspor, melalui pendekatan penerapan sains dan teknologi tepat guna, peningkatan kualitas dan kuantitas produksi, serta penguatan kapasitas kelembagaan. Pendampingan terhadap Rotan Indah Jepara penting dilakukan mengingat peran strategis industri ini, dalam bentuk peningkatan kesejahteraan pelaku usaha, masyarakat sekitar hingga pendapatan negara melalui pendapatan asli daerah.

Tujuan yang ingin dicapai dari pelaksanan pengabdian yaitu meningkatkan pengetahuan dan ketrampilan mitra sehingga memacu pertumbuhan produk kerajinan rotan untuk pasar dalam negeri maupun pasar internasional, meningkatkan kualitas dan kuantitas kerajinan rotan sebagai produk unggulan daerah yang berdaya saing, dan mempercepat difusi teknologi 
pada mitra melalui implementasi teknologi tepat guna. Sedangkan target khusus yang akan dicapai yaitu adanya perluasan pasar ekspor bagi produk kerajinan rotan khususnya produk kerajinan anyaman rotan di Jepara, serta penguatan kerajinan anyaman rotan sebagai industri kreatif dengan ciri khas daerah.

Melalui program pengabdian ini. Dampak dan manfaat kegiatan diantaranya dilihat dari perubahan sosial, efektivitas dan peningkatan produktivitas, sebagai dampak dari adanya perubahan pola kerja, sistem dan teknologi yang digunakan. Perubahan sosial adalah perubahan yang terjadi sebagai suatu variasi dari cara hidup dengan paradigma baru dikarenakan adanya perubahan kondisi, budaya, material, difusi teknologi ataupun penemuan-penemuan baru dalam masyarakat (Murtiasri \& Pendahuluan, 2010).

Wujud kontribusi yang diberikan yaitu menyiapkan tatakelola manajemen dan administrasi yang baik, pendampingan perijinan/legalitas usaha dan pendampingan tatakelola ekspor sehingga mitra program memiliki kapasitas untuk melaksanakan ekspor secara mandiri, selain itu juga dilakukan pendampingan pada proses produksi melalui diseminasi dan implementasi teknologi tepat guna, pendampingan desaign dan inovasi produk dan pendampingan pemasaran dan promosi yang tepat, sehingga dihasilkan kualitas produk yang baik, kuantitas produk yang mencukupi permintaan pasar, dan proses pemasaran dan layanan penjualan yang baik.

\section{METODE PELAKSANAAN}

Beberapa permasalahan yang berkaitan dengan UKM mitra secara umum dapat dikategorikan kedalam beberapa bidang, yaitu bidang produksi, manajemen, pemasaran dan SDM. Bidang produksi, permasalahan yang dihadapi yaitu kualitas dan kuantitas produk rendah, keterbatasan mesin dan kapasitas mesin rendah, tempat produksi terbatas, pemrosesan barang semi manual, serta inovasi yang rendah. Bidang manajemen, kendala yang dihadapi belum memiliki legalitas usaha, manajemen perusahaan masih tradisional, belum ada mekanisme tatakelola produksi yang baik, belum dilakukan pengelolaan keuangan dan akuntansi dengan baik, layanan penjualan dan purna jual belum dikelola dengan baik. Pada bidang pemasaran, masih tradisional mengandalkan pesanan, ketergantungan pemasaran pada perusahaan besar dan terbatas pada pasar lokal, belum ada upaya promosi. Sedangkan dalam bidang SDM, jumlah tenaga kerja terbatas, pengetahuan tentang perjanjian kerja, keamanan dan jaminan yang rendah serta perputaran tenaga kerja yang tinggi, hal ini dilatar belakangi karena banyak tenaga trampil yang pindah sebagai pekerja pabrik, yang saat ini banyak berdiri di Jepara.

Dari permasalahan tersebut, metode yang digunakan untuk menyelesaikan masalah dan pencapaian tujuan program pengabdian yaitu kemandirian ekspor bagi UKM binaan, ditetapkan program pencapaian dalam tiga tahapan. Tahap pertama, penguatan kelembagaan serta peningkatan 
kualitas dan kuantitas produk, dilaksanakan melalui program penguatan manajerial usaha, melengkapi perijinan usaha, peningkatan ketrampilan produksi, pengembangan media pemasaran dan peningkatan teknologi produksi. Tahap kedua, pengembangan produk dan peningkatan kualitas dan kuantitas produk, dilaksanakan melalui program pengembangan kualitas produk, pengembangan pemasaran, dan peningkatan teknologi produksi. Tahap ketiga, pengembangan produk dan pemasaran ekspor, melalui pelaksanaan kegiatan berupa pengembangan produk ekspor, legalitas ekspor, pengembangan peralatan produksi serta peningkatan kualitas dan kuantitas produk.

Program pengabdian yang dilaksanakan ini merupakan tahap pelaksanaan tahap pertama, dilakukan empat kegiatan, yaitu 1) penguatan peralatan produksi dan implementasi teknologi tepat guna, 2) penguatan kapasitas dan kualitas produk, 3) penguatan kapasitas pemasaran, dan 4) penguatan tatakelola perusahaan dan penyusunan sistem akuntansi dan pelaporan keuangan terkomputerisasi.

Diseminasi teknologi tepat guna, dilakukan sesuai dengan target peningkatan kapasitas produksi yang direncanakan adanya peningkatan kapasitas produksi sejumlah $25 \%$ dari produksi yang dapat dihasilkan sebelumnya. Dilakukan melalui penambahan peralatan dan mesin baru dan diseminasi peralatan produksi. Penguatan kapasitas produksi dan kualitas produk dilaksanakan melalui pendampingan proses produksi akhir dan finishing yang lebih berkualitas serta pendampingan inovasi produk baru. Penguatan kapasitas pemasaran dilaksanakan melalui pendampingan pemasaran online, penyusunan profil perusahaan dan katalog produk serta pendampingan pada akses terhadap pemerintah daerah atau even organizer untuk keikutsertaan dalam pameran kerajinan berskala internasional. Sedangkan program penguatan kapasitas kelembagaan dilaksanakan melalui pendampingan terhadap perijinan usaha, penyusunan sistem administrasi dan manajerial perusahaan, penyusunan sistem akuntansi dan perpajakan terkomputerisasi serta penyusunan prosedur mutu produksi.

\section{HASIL DAN PEMBAHASAN}

UKM Rotan Indah Jepara merupakan industri kecil yang bergerak dalam bidang kerajinan (handmade handycraft), yang terletak di Dukoh Kalipucang Kulon Kecamatan Welahan Kabupaten Jepara. Berada dalam suatu kawasan sentra industri kerajinan rotan di Jepara. Kerajinan rotan merupakan salah satu dari 12 industri kecil dan menengah yang ada di Kabupaten Jepara dengan unit usaha sejumlah 846 unit serta mampu menyerap tenaga kerja sejumlah 4.665 orang (BPS Jepara, 2016). UKM Rotan Indah Jepara memiliki tenaga kerja sejumlah 25 orang pada bagian produksi, sebagian besar didominasi oleh tenaga kerja laki-laki sejumlah 24 orang $(92,31 \%)$ dan tenaga kerja perempuan sejumlah 2 orang $(7,69 \%)$. Dalam menjalankan produksinya menempati gudang sebagai tempat produksi seluas $225 \mathrm{~m}^{2}$. Produk yang dihasilkan antara 
lain kursi makan, kursi teras, sofa, daybed, ayunan, handicraft, lampu hias dan Gazebo. Kapasitas produksi sejumlah 280 pcs/bulan, dengan nilai investasi sejumlah 2 milyar.

Masalah secara umum yang dihadapi oleh UKM mitra yaitu kualitas dan kuantitas produk rendah, keterbatasan mesin dan kapasitas mesin rendah, tempat produksi terbatas, pemrosesan barang manual, ketergantungan cuaca dan suplai listrik serta inovasi yang rendah. Dalam bidang manajemen persoalan pada manajemen perusahaan masih tradisional, belum ada mekanisme tatakelola produksi yang baik, belum dilakukan pengelolaan keuangan dan akuntansi dengan baik, layanan penjualan dan purna jual belum dikelola dengan baik. Bidang pemasaran persoalan pemasaran masih tradisional mengandalkan pesanan, ketergantungan pemasaran produk pada perusahaan besar dan terbatas pada pasar lokal, belum ada upaya promosi. Sedangkan bidang SDM, jumlah tenaga kerja terbatas, pengetahuan tentang perjanjian kerja, keamanan dan jaminan yang rendah serta perputaran tenaga kerja yang tinggi, karena banyak tenaga trampil yang pindah sebagai pekerja pabrik.

Kerajinan rotan yang diproduksi oleh UKM Rotan Indah Jepara selain dibuat dengan menggunakan bahan rotan alam juga dibuat kerajinan rotan dengan menggunakan rotan sintetis. Semakin berkurangnya pasokan dan mahalnya harga rotan alam, sehingga mulai banyak digunakan bahan rotan sintetis. Bahan baku yang digunakan dalam proses produksi meliputi Rotan alam, Rota sintetis, Eceng gondok, Debog, Kayu, Alumunium, Besi, Stainlies, Busa, Kain oscar dan Kain waterpruf. Bahan baku yang dibutuhkan tersebut berasal dari berbagai wilayah, untuk rotan sintetis didapat dari Jakarta, Surabaya dan Semarang sedangkan bahan rotan alam didapat dari Kalimantan. Adapun untuk bahan-bahan yang lainnya didapatkan dari wilayah sekitar Kabupaten Jepara.

Dalam proses produksi UKM Rotan Indah Jepara sebetulnya telah menggunakan beberapa peralatan mesin dalam proses produksinya. Selain kebutuhan tenaga kerja manusia untuk menjalankan mesin, utamanya proses penganyaman rotan yang membutuhkan tenaga kerja manusia yang trampil. Peralatan yang dimiliki oleh UKM mitra diantaranya mesin kompresor, mesin tembak, mesin las, mesin bor kayu, alat potong kayu, alat potong besi, alat pemotong alumunium, alat pasah/ketam, mesin juwinter, mesin planer, alat rol alumunium, gunting solder dan hardrayer.

Proses produksi kerajinan rotan di UKM Rotan Indah Jepara dapat digambarkan, 1) Pembuatan frame (kerangka dasar). Frame dibuat dari bahan kayu, besi, stainlies maupun alumunium, penggunaan bahan sesuai dengan jenis barang yang akan dibuat; 2) Pengecetan frame. Setelah frame di rangkai setengah jadi sesuai pola yang ada, kemudian dilakukan pengecatan; 3) Penganyaman. Setelah frame selesai dikerjakan dan pengecatan hingga kering, kemudian menuju proses penganyaman, menggunakan rotan alam maupun rotan sitetis; dan 4) Pemasangan asesories. Proses berikutnya yaitu 
memberikan asesories pada produk yang dibuat, jenis asesories yang diberikan beragam sesuai jenis produk dan pesanan, dalam bentuk label, sepatu dan bantalan.

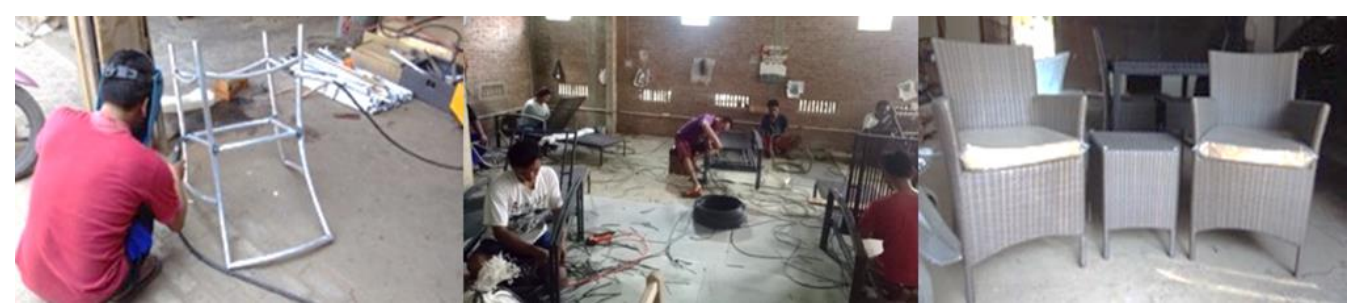

Gambar 1. Proses produksi pada UKM Rotan Indah Jepara

Pengelolaan manajerial pada UKM Rotan Indah Jepara masih menggunakan sistem tradisional dimana pemilik sekaligus yang menjalankan usaha. Manajerial perusahaan dikendalikan personal oleh pemilik perusahaan. Belum ada struktur organisasi maupun distribusi pekerjaan, seluruh aktivitas dikendalikan oleh pemilik perusahaan, mulai dari pemesanan bahan, proses pemasaran dan pengelolaan keuangan dan pencatatan akuntansinya. Dalam pemasaran pemilik langsung turun ke pasar untuk memasarkan produknya. Dalam pencatatan dan proses akuntansi masih sederhana belum menggunakan sistem akuntansi yang standar.

Pemasaran pada UKM Rotan Indah Jepara masih menggunakan model langsung ke pelanggan. Pemilik langsung melakukan pemasaran sendiri ke berbagai pelanggan yang ada di beberapa daerah. Selain itu pemasaran juga telah diupayakan online melalui website maupun media jejaring sosial.

Dari permasalahan yang dihadapi tersebut, dilaksanakan empat kegiatan, yaitu 1) penguatan peralatan produksi dan implementasi teknologi tepat guna, 2) penguatan kapasitas dan kualitas produk; 3) penguatan kapasitas pemasaran; 4) penguatan tatakelola perusahaan, penyusunan sistem akuntansi dan pelaporan keuangan terkomputerisasi.

\section{Penguatan Kapasitas Kelembagaan dan implementasi teknologi tepat guna.}

Program ini dilaksanakan melalui berbagai kegiatan peningkatan kemampuan tatakelola, administrasi, manajemen SDM, perjanjian kerja dan kontrak kerja, dan menyusun sistem tatakelola. Dalam pendampingan sistem tatakelola dilakukan pelatihan pengelolaan manajerial usaha meliputi tatakelola administrasi dan produksi. Tatakelola administrasi dan produksi dilaksanakan melalui pengadaan kebutuhan dokumen administrasi dan produksi, diantaranya, buku agenda surat, buku order/produksi, kartu nama, invoice, surat jalan, kop surat, kop amplop dan map perusahaan.

Untuk peningkatan mutu produk, maka dilaksanakan program pendampingan manajemen mutu, dengan target capaian dimilikinya 
dokumen mutu produksi dan dicapainya kualitas produk standar ekspor, melalui kegiatan pendampingan penguatan sistem manajemen mutu; dan penyusunan sistem manajemen mutu. Selain melaksanakan penyusunan dokumen mutu dan pelatihan manajemen mutu, juga dibuat desain label produk.

Kondisi mitra program saat dilakukan pendampingan belum memiliki perijinan usaha. Berdasarkan pada pernyataan mitra program, hal tersebut dilatarbelakangi oleh kekhawatiran pada pembayaran pajak, ketika sudah memiliki ijin usaha maka akan berdampak pada kewajiban membayar pajak. Pentingnya ijin usaha bagi pelaku UKM, diantaranya mendapatkan jaminan perlindungan hukum, memudahkan dalam pengembangan usaha, membantu memudahkan dalam pemasaran usaha, akses pembiayaan yang lebih mudah, dan memperoleh pendampingan usaha dari pemerintah maupun lembaga lainnya.

Kekhawatiran oleh pihak UKM tersebut, maka melalui program pengabdian ini dilakukan pendampingan dalam bentuk memberikan pemahaman berkaitan dengan ijin usaha dan pelatihan pengelolaan keuangan dan pajak. Melalui program pendampingan, saat ini Rotan Indah Jepara telah memiliki perijinan usaha dalam bentuk CV. Untuk mendukung proses pengelolaan keuangan yang baik, dilakukan pendampingan pengelolaan keuangan.

Proses pendampingan pengelolaan keuangan dilakukan dengan memberikan pemahaman pengelolaan keuangan, dari yang paling sederhana yaitu mengumpulkan bukti-bukti transaksi disimpan dan dibukukan, membuat buku kas manual setiap transaksi keuangan. Pada tahap awal ini, belum diberikan aplikasi akuntansi yang terkomputerisasi, namun menanamkan pemahaman prosedur dan alur pengelolaan keuangan. Setelah memiliki kebiasaan melakukan pencatatan setiap transaksi yang dilakukan dan pemahanan terhadap alur akuntansi kemudian diberikan aplikasi yang terkomputerisasi, untuk memudahkan proses pengelolaan dan pencatatan keuangan.

\section{Peningkatan Kapasitas \& Peralatan Produksi}

Program berikutnya yang dilaksanakan yaitu peningkatan kapasitas dan peralatan produksi, dilaksanakan melalui kegiatan penambahan peralatan produksi dan diseminasi mesin/alat teknologi produksi, pendampingan proses produksi yang berkualitas, dan pendampingan inovasi desain produk.

Rotan Indah Jepara sebelum pendampingan tidak mencatat volume produksi dan penjualan, sehingga tidak dapat diketahui perkembangan produksinya. Melalui program pengabdian ini diharapkan memberikan dampak peningkatan kuantitas dan kualitas produksi. Data perkembangan produksi dimonitoring sejak April 2019, sedangkan pada bulan sebelumnya tidak diketahui secara persis jumlah produksinya karena tidak dilakukan 
pencatatan. Hal ini menjadi salah satu program pendampingan peningkatan tatakelola manajemen. Pada bulan April memproduksi sejumlah 120 unit dengan nominal Rp.40.000.000,-, bulan Mei sejumlah 150 unit (Rp.65.000.000,-), bulan Juni sejumlah 185 unit (Rp.85.000.000,), dan bulan Juli sejumlah 200 unit (Rp.105.000.000,-) atau rata-rata terdapat kenaikan produksi sejumlah $15 \%$.

Melalui program pengabdian ini juga dilakukan diseminasi teknologi tepat guna (TTG) ke UKM mitra guna meningkatkan peralatan yang telah miliki sebelumnya. Diseminasi teknologi ini untuk meningkatkan kuantitas dan kualitas produksi, juga dilakukan perluasan tempat usaha, karena gudang produksi yang ada tidak mencukupi kapasitas dengan adanya penambahan peralatan dan program peningkatan produksi. Upaya peningkatan produktifitas selain melalui diseminasi TTG juga juga dengan peralatan yang bersifat masinal. Peralatan yang bersifat masinal yang penting untuk ditingkatkan yaitu pada aspek finishing. Peningkatan peralatan produk dengan finishing menjadi penting, karena dengan finishing sebuah produk dapat meningkatkan penjualannya (Purnomo, Sumarno, \& Hartomo, 2018). (Edquist, 2013) menyatakan bahwa inovasi teknologi memberikan perubahan baik dari segi fisik peralatan, teknik dan system. Selanjutnya Edquist mengelompokkan tingkat teknologi dalam UKM menjadi teknologi tradisional, teknolgi standar dan teknologi transisi baik digunakan pada peralatan, proses produksi dan sistemnya. Semakin rendah tingkatannya, maka semakin sederhana teknologi yang digunakan yang berarti semakin banyak tenaga manusia digunakan secara manual. Tantangan dalam penerapan teknologi dalam UKM umumnya terdapat pada kemampuan investasi dan pengetahuan SDM dalam mengikuti perkembangan teknologi (Kuncoro, 2017).

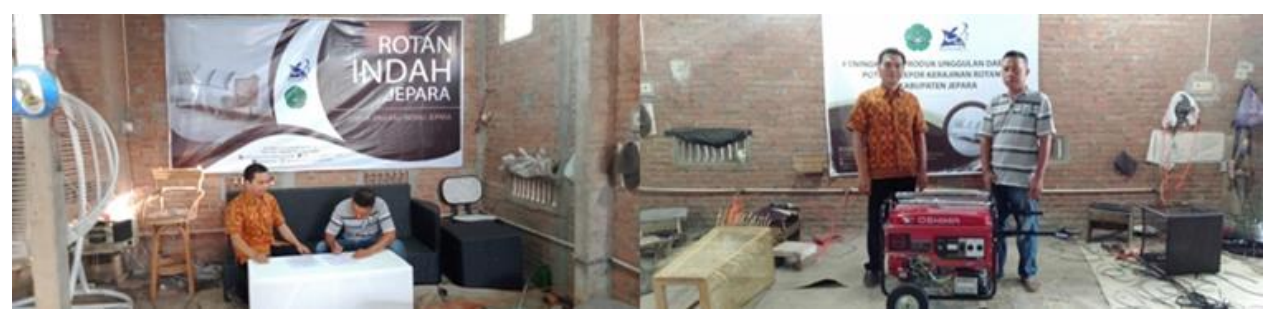

Gambar 2. Penandatanganan berita acara penyerahan diseminasi teknologi ke UKM

Dalam pendampingan inovasi desain produksi, tim pengabdian mengembangkan berbagai desain dan inovasi produk. Hasil dari pengembangan desain produk ini diajukan HKI dan dibuat prototype untuk ditampilkan dalam pameran berskala internasional. Desain dan inovasi produk yang dibuat diantaranya yaitu desain produk umplung payung dan dan desain produk meja computer berbahan dasar rotan. Tahap pengembangan berikutnya yaitu memampuan dari mitra program untuk 
melakukan inovasi dan modifikasi dari desain yang ada maupun kreatifitas dalam membuat desain baru yang inovatif.
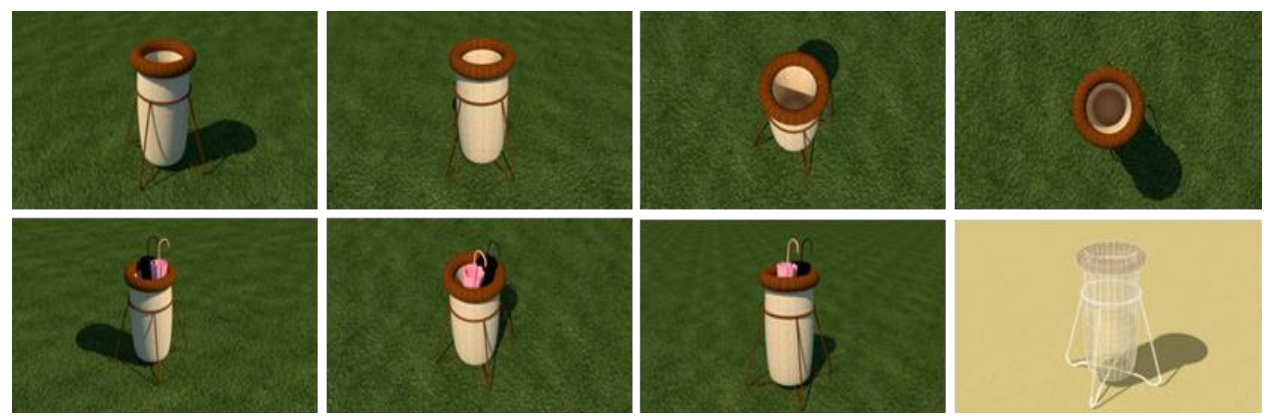

Gambar 3. Konsep inovasi produk Umplung Payung salah satu hasil inovasi desain produk program pendampingan mitra

\section{Peningkatan Kapasitas Pemasaran}

Program peningkatan kapasitas produksi dilaksanakan kegiatan berupa pengembangan media pemasaran online, pembuatan profil perusahaan dan katalog produk, serta mengikuti event pameran berskala internasional dan pengembangan media pemasaran online. Pengembangan media pemasaran online melalui pengembangan website, facebook dan Instagram yang menarik dan informatif. Diantara yang dilakukan yaitu melakukan pendampingan penyusunan konten publikasi yang menarik dan informatif. Menampilkan berbagai gambar dan spesifikasi produk, informasi bahan dan kualitas produk serta mekanisme pemesanan produk.

Kendala yang sering dialami oleh UKM yaitu tidak memiliki produk yang didiplay sebagai contoh hasil produksi. UKM biasanya tidak menyiapkan secara khusus contoh produk yang dihasilkannya baik dalam bentuk wujud fisik barang maupun gambar yang dibuat khusus. Dilakukan pendampingan pembuatan katalog produk yang manarik dan informatif, dalam bentuk cetak maupun elektronik, untuk bahan promosi pada pameran maupun untuk promosi online pada website maupun media social lainnya.

\section{Penguatan Tatakelola Perusahaan}

Dalam program pendampingan pengelolaan keuangan, akuntansi dan pelaporan pajak, dilaksanakan beberapa kegiatan penyusunan sistem informasi akuntansi dan perpajakan, serta pendampingan pengelolaan keuangan. Belum adanya pembukuan dan belum dilakukannya penghitungan harga pokok, sedangkan penentuan harga ditetapkan berdasarkan biaya bahan baku, biaya upah tenaga kerja dan biaya overhead yang dibagi rata antar varian produk serta tidak mempertimbangkan laporan biaya. Pemilik usaha merasa usahanya 
memiliki banyak keuntungan padahal ada beberapa produk yang penentuan harga jualnya lebih rendah bila dibandingkan dengan biaya yang dikeluarkan untuk produksi. (Sari, Tantrika, Lukodono, \& Widiyawati, 2018) menyatakan perlunya sistem informasi yang dapat membantu UKM menentukan harga pokok produksi dengan mudah dan cepat yang mempertimbangkan aktivitas produksi.

Dari berbagai program pendampingan yang telah dilaksanakan, meliputi penguatan kapasitas kelembagaan dan implementasi teknologi tepat guna, peningkatan kapasitas dan peralatan produksi, peningkatan kapasitas pemasaran dan penguatan tatakelola perusahaan. Memberikan dampak perbaikan manajerial berupa perbaikan administrasi pengelolaan usaha lebih profesional, peningkatan kualitas dan kuantitas produksi, penguatan peralatan produksi maupun pengembangan pemasaran.

\section{KESIMPULAN}

Berdasarkan pada permasalahan yang dihadapi oleh UKM mitra, pada tahap awal pelaksanaan program pengabdian ini diarahkan pada pencapaian tujuan yaitu penguatan kapasitas kelembagaan dan peningkatan kuantitas dan kualitas produksi, sehingga produk akhir memiliki kualitas produk untuk sasaran ekspor.

Ketercapaian target menunjukkan ketepatan metode pendampingan yang ditetapkan. Beberapa program yang dijalankan, yaitu 1) penguatan peralatan produksi dan implementasi teknologi tepat guna, 2) penguatan kapasitas dan kualitas produk; 3) penguatan kapasitas pemasaran; 4) penguatan tatakelola perusahaan, penyusunan sistem akuntansi dan pelaporan keuangan terkomputerisasi. Semua target yang ditetapkan pada tahap awal ini dapat direalisasikan, serta terdapat program yang harus dilanjutkan pada tahap kedua yaitu penguatan peralatan produksi dan implementasi teknologi tepat guna, penguatan kapasitas dan kualitas produk, serta penguatan kapasitas pemasaran.

Dampak dan manfaat kegiatan diantaranya dapat dilihat dari perubahan sosial, efektivitas dan peningkatan produktivitas, sebagai dampak dari adanya perubahan pola kerja, sistem dan teknologi yang digunakan. Kegiatan pengabdian ini mampu memberikan nilai perubahan sosial berwujud peningkatan efektivitas, produktivitas dan motivasi kerja dari UKM mitra binaan. Efektivitas yang dimaksud adanya perubahan pola kerja menjadi lebih baik. Dilaksanakannya program penguatan tatakelola perusahaan, penyusunan sistem akuntansi dan pelaporan keuangan, berdampak pada perubahan pola kerja pada UKM mitra. Peningkatan kemampuan tatakelola manajerial meliputi tatakelola administrasi dan produksi, tatakelola SDM dalam bentuk pengelolaan perjanjian kerja dan kontrak kerja. Tatakelola administrasi dan produksi juga disusun kelengkapan dokumen administrasi dan produksi, selain itu juga telah dimilikinya sistem akuntansi dan pelaporan keuangan dan legalitas usaha dalam bentuk CV. 
Peningkatan produktivitas dapat dilihat dari adanya peningkatan kapasitas produksi dan omset penjualan setiap bulannya menunjukkan tren meningkat sekitar $15 \%$ dari sebelumnya. Data perkembangan produksi dimonitoring sejak April 2019, sedangkan pada bulan sebelumnya tidak diketahui secara persis jumlah produksinya karena tidak dilakukan pencatatan.

Dari seluruh program yang dilaksanakan menumbuhkan peningkatan motivasi kerja, adanya keberanian pengrajin melengkapi ijin usaha, pada awalnya tidak dilakukan karena kekawatiran berhubungan dengan pelaporan pajak, perubahan pengelolaan administrasi, produksi dan pengelolaan keuangan, pola kerja yang lebih baik yang terbentuk diharapkan dapat menjadi kebiasaan atau budaya kerja sebagai seorang entrepreneur.

Perkembangan sosial mitra ditunjukkan adanya peningkatan jumlah omset penjualan. Peningkatan penjualan disebabkan salah satunya karena peningkatan kapasitas produksi yang ditunjang peralatan dan peningkatan mesin baru serta upaya promosi dan pelayanan konsumen yang lebih baik. Value added yang lain ditunjukkan adanya penghematan yang cukup signifikan dari pola manajemen yang baik dan proses produksi yang lebih efisien sehingga mampu mengurangi biaya produksi yang berdampak pada meningkatkan kapasitas produksi.

Kesimpulan yang terakhir namun sangat berarti adalah pentingnya perubahan pola pikir pada pengrajin menjadi seorang entrepreneur, keberanian dan motivasi pengrajin dalam melakukan perubahan, keluar dari zona nyaman bahwa bekerja dari yang biasanya dianggap sudah cukup untuk dapat memenuhi kebutuhan, menjadi mental seorang entrepreneur yang handal dan terus meningkatkan daya saing.

\section{UCAPAN TERIMA KASIH}

Program pengabdian yang dilaksanakan merupakan skema Program Pengembangan Produk Ungulan Daerah (PPPUD) tahun 2019. Tim pengabdian mengucapkan terimakasih kepada:

1. Kementerian Ristek DIKTI, Direktorat Riset dan Pengabdian Kepada Masyarakat yang telah menfasilitasi pelaksanaan program pengabdian kepada masyarakat;

2. Lembaga Penelitian dan Pengabdian Kepada Masyarakat, Universitas Islam Nahdlatul Ulama Jepara, yang telah mengkoordinasikan pelaksanaan kegiatan pengabdian masyarakat dengan baik;

3. UKM Rotan Indah Jepara, sebagai mitra program dalam pelaksanaan program PPPUD, dan telah secara aktif ikut berpartisipasi dalam program pengabdian ini.

\section{DAFTAR RUJUKAN}

Alamsyah. (2019). Eksistensi Industri Kerajinan Rotan di Teluk Wetan Jepara. ANUVA, 3(1), 33-46. 
Anam, A. K., \& Setiawan, M. (2019, Juni). Strategi Pengembangan Produk Unggulan Daerah Berbasis Klaster pada Sentra Kawasan Industri Rotan di Kabupaten Jepara. MANDAR (Management Development and Applied Research Journal), 1(2), 1-8.

Anam, A. K., \& Susilo, E. (2018). Peningkatan Produktivitas dan Manajemen Usaha pada Pengrajin Rotan Melalui Implementasi Teknologi Tepat Guna. Jurnal Pengabdian dan Pemberdayaan Masyarakat (JPPM) LPIP UMP, 2(2), 185-191.

Bigliardi, B., Colacino, P., \& Dormio, A. I. (2011). Innovative Characteristics of Small and Medium Enterprises. Journal of Technology Management \& Innovation, 6(2), 83-93.

BPS. (2016). Kabupaten Jepara Dalam Angka 2016. Jepara: BPS Kabupaten Jepara.

Edquist, C. (2013). Systems of Innovation: Technologies, Institutions and Organizations. London: Routledge.

Kuncoro, D. K. (2017). Identifikasi Eco-Inovasi pada Usaha Mikro dan Kecil Kerajinan Rotan Berdasarkan Tipe, Sumber Informasi dan kemampuan Teknologi. Prosiding Seminar Nasional Teknologi IV (pp. 34-41). Samarinda: Fakultas Teknik, Universitas Mulawarman.

Kurniaty, R. M., Fauzi, A. M., \& Chozin, M. A. (2012, November). Daya Saing PT Benar Flora Utama Berdasarkan Aktivitas Rantai Nilai Florikultura. Jurnal Manajemen \& Agribisnis, 9(3), 146-153.

Murtiasri, E., Suharto, \& Sartono. (2015, Oktober). Peningkatan Kualitas Produk dan Kompetensi Pengrajin Wayang Kulit Menuju Pasar Sasaran Ekspor. Dian Mas, 4(2), 71-82.

Purnomo, A., Sumarno, \& Hartomo, D. D. (2018). Pengembangan Industri Kerajinan dan Mebel Rotan Berbasis Kearifan Lokal. Seminar Nasional dan Pameran Hasil Penelitian \& Pengabdian Masyarakat, Seni, Teknologi dan Masyarakat \#3 (pp. 118-123). Surakarta: Institut Seni Indonesia Surakarta.

Sari, R. A., Tantrika, C. F., Lukodono, R. P., \& Widiyawati, S. (2018). Penentuan Harga Produk Kerajinan Rotan berbasis Aktivitas. Jurnal Teknik Industri ITN Malang, 15-20. 